\title{
Assessing the appropriation of social media by academic librarians in South Africa and Zimbabwe
}

\author{
Rangarirai Moira Mabweazara ${ }^{1}$ and Sandy Zinn $^{2}$ \\ 3371267@myuwc.ac.za ORCID: orcid.org/0000-0003-3536-6523 \\ szinn@uwc.ac.za ORCID: orcid.org/0000-0002-0212-0036
}

\begin{abstract}
Received: 10 January 2016
Accepted: 31 May 2016

Research into the appropriation of social media by academic libraries in countries with growing economies is scarce. There remains an empirical and theoretical gap in the literature about how librarians, particularly those in Southern Africa, are deploying social media in their work routines and in their personal lives. Based on one of the researchers' experiences at the National University of Science and Technology (NUST) Library and both researchers' use of the University of the Western Cape (UWC) Library, the researchers aimed to examine the way librarians deploy and appropriate social media platforms as part of their service delivery. Using data derived from a questionnaire survey among librarians at UWC in South Africa and NUST in Zimbabwe, this study examined how librarians use social media for professional and personal purposes. The findings suggest that UWC librarians are more proficient social media users than NUST librarians. They further reveal that UWC librarians themselves are managing social media, while at NUST, the Information Technology department is directly responsible for managing the platforms. The study found that UWC Library utilises social media to promote its services more widely, whereas the NUST Library uses social media for reference services.
\end{abstract}

Keywords: Social media, Technological Acceptance Model (TAM), academic libraries, National University of Science and Technology (NUST), University of the Western Cape (UWC)

\section{Introduction}

University libraries in Africa are constantly pressured to provide their patrons with quality services. Quality library services are important because today's library users live in a highly interactive and networked world which already largely provides for their information needs (Kibugi 2013). As social media increasingly becomes a strategic resource for university education, its adoption and use is no longer a choice for academic libraries. By definition, social media platforms are powerful technological tools for communication, loosely summed up as technologies used for interacting, creating and sharing information all "built on the ideological and technological foundations of Web 2.0" (Kaplan \& Haenlein 2010: 61). Social media applications have become critical for librarians as they allow them to be more active in the international information arena; at the same time, they offer innovative services for the library to make use of. In line with this view, Witte (2014) maintains that "there is a notable shift from using social media as the voice of the institution to being the voice of a librarian within the institution". In order to embrace these requirements successfully, librarians must be competent in the use of social media applications; this competency is requisite for the twenty-first century librarian (Vanwynsberghe et al. 2015).

Academic libraries are particularly strategic in comparison to other libraries in that they offer research and knowledge exchange activities that underpin the very existence of their parent institutions. As such, academic libraries are crucial to the operation of tertiary institutions and their academic quests (Moran \& Leonard 2009: 2). Tripathi and Kumar (2010: 195) state that, previously, academic libraries were "place-based" services within universities; patrons physically went to the library to consult librarians and/or to use the physical collections. Due to the overwhelming success of internet services, academic libraries have been able to introduce virtual services that make use of new technologies - social media, for example. Social media platforms lend themselves to enabling closer ties between libraries and users, irrespective of geographical distance (Oosman, McMillan \& Bell 2014).

There is a need for robust internet connectivity within universities in order to fully support educational demands (Kruss \& Gastrow 2015: 18). The Tertiary Education and Research Network of South Africa (TENET) operates the South African National Research Network (SANReN) which ensures affordable, first-preference and efficient internet access to public universities in South Africa (Wright 2011). The University of the Western Cape, among other institutions, is enjoying these internet privileges. The superior internet connection directly helps the UWC Library in fulfilling its mission to support teaching, learning, and research by making available relevant resources, employing suitable staff, and offering an

1. Rangarirai Moira Mabweazara is a PhD student in the Department of Library and Information Science, University of the Western Cape, South Africa

2. Sandy Zinn is Departmental Chairperson and Senior Lecturer in the Department of Library and Information Science, University of the Western Cape, South Africa 
environment favourable for patrons' knowledge acquisition. The library has appropriated mobile technologies such as iPads, which are used for teaching and learning in an 'iPad laboratory' situated inside the library, as well as e-readers which are available for patrons to borrow on a short-loan basis.

In Zimbabwe, approximately thirty-one percent of the national budget is allocated to higher education, although currently universities rely heavily on student fees. Chitanana (2012) maintains that Zimbabwean universities have made significant strides towards increasing their bandwidth and improving their networks. As a result of these investments, the NUST Library is under pressure to utilise effectively the latest technologies for service and information provision to the university community. Among other resources, the library has a digital library, which is offered through Greenstone (free software found online, provided by UNESCO) and a mobile site that allows library access to remote users who are using mobile technologies.

The growing popularity and usage of new technology applications among tertiary institutions, as indicated above, has pointed to the need for a mutual effort in the effective adoption and deployment of social media platforms among university libraries as a way of ensuring excellent service provision. Therefore, this paper addresses how UWC and NUST library staff use social media in their work routines and in their everyday lives. The paper specifically seeks to answer the following questions:

- How familiar are the library staff with social media and which tools do they use mostly?

- Where do they access social media?

- $\quad$ For what purposes do library staff use social media tools?

- And, what factors shape and constrain library staff's use of social media tools?

\section{Research methodology and theoretical framework}

To help answer the aforementioned research questions, this research is underpinned by the Technological Acceptance Model (TAM) propounded by Fred Davis in 1989. It consists of two variables: the 'perceived usefulness' and 'perceived ease of use' of the relevant technology. 'Perceived usefulness' is defined here as the "degree to which a person believes that using a particular system would enhance his or her job performance". 'Perceived ease of use', on the other hand, refers to the "degree to which a person believes that using a particular technological system would be free of effort". The model is relevant to this study as it has been used in similar studies to investigate intention of use and adoption of technology among individuals. Examples of such studies include research done by Aharony (2013), who fused the TAM and the Big Five model of personality traits, and Spacey, Goulding and Murray (2004), who used the TAM to find out about the adoption and use of internet technology among librarians in the United Kingdom (UK).

Methodologically, the study used a case study research design, defined as a "method of studying elements of the social through comprehensive description and analysis of a situation, for example a detailed study of a group or event" (O'Leary 2004: 23). The study made a closer inspection of two cases, paying particular attention to how librarians at NUST and UWC libraries use social media technologies. The study further employed a web-based questionnaire which was sent to fifty-nine UWC librarians; forty-three (72.8\%) responses were received. Of forty NUST librarians, twenty-nine responded, representing a response rate of $72.5 \%$.

\section{Literature review}

Since the introduction of social media into academic libraries, scholars, particularly those in the economically developed countries of the north, have been researching the adoption and appropriation of these technologies among library staff. Recent research has found that librarians are out of touch with the technological changes in their profession. This detachment has impacted negatively on their level of familiarity with social media. However, other studies have revealed that librarians across different types of libraries are using social media more and more, mostly because they are required to do so by senior management (Aharony 2009).

Facebook and Twitter are common social media tools used by librarians in the UK, while tags are commonly used by librarians in Asia (Gerolimos \& Konsta 2011), RSS and bookmarks by librarians in Midwest America (Mahmood 2011; Kim \& Abbas 2010), and Twitter, Facebook and YouTube by Canadian librarians (Collins \& Quan-Haase 2012). The use of social media tools in academic libraries is said to be gaining momentum in some African countries. Ezeani and Igwesi (2012) stated that social media tools such as Facebook, MySpace, Twitter and YouTube are increasingly being used by librarians and patrons in Nigerian academic libraries. Similarly, Facebook, blogs, YouTube, wikis, gaming and Skype are commonly used by librarians at the University of Pretoria (Penzhorn \& Pienaar 2009). From the above, it is clear that there is little difference in the types of social media used by library staff across the world.

Every academic library has its own purposes for using social media. Three major purposes for social media adoption in academic libraries are identified in the literature and discussed below.

\subsection{Marketing and promotion of information services}

Harinarayana and Raju (2010) maintain that social media technologies are becoming increasingly popular for use in academic libraries' marketing strategies. Social media tools have assisted university libraries in the promotion of information services to their patrons (Makori 2011: 35). It is becoming the norm for librarians to use these technologies as communication tools - to tweet or post on their Facebook page, for example - thereby instantly reaching out to as many users as possible. Users no longer have to go to the library to check on the traditional notice boards about what the library 
wants to communicate to them. In his study, Rogers (2009) found that it is becoming routine for academic libraries in the United States of America to use Web 2.0 applications such as social networks and blogs to promote and market library services.

\subsection{Online interaction}

Instant interaction between a librarian and the user is one of the many reasons academic libraries have chosen to integrate social media tools into their daily work. Social media tools such as YouTube, MySpace, Facebook, Twitter and Flickr are popular for online collaboration, communication and sharing of information among librarians (Makori 2011: 34) and instant messaging (IM) provides the basis for librarians to interact with their patrons (Munatsi 2010: 255). Simply put, librarians are now able to communicate instantly with users by remotely providing assistance such as virtual reference services (Stephens 2006) and to offer current information to students and researchers (Xu, Ouyand \& Chu 2009). This means, for example, that, instead of arranging face-to-face orientation programs, academic libraries are increasingly using RSS feed readers, podcasts and recorded videos to deliver audio and video commentary and instruction to users remotely.

\subsection{Supporting open and distance learning (ODL) and offering information literacy programmes}

E-learning is becoming more prevalent in tertiary education, with universities increasingly using online learning environments and more students comfortably accepting them. Academic library staff have a significant role to play in supporting universities offering e-learning courses by deploying social media technologies. Worldwide, university libraries are making inroads into the use of social media tools in order to meet the information needs and demands of students in ODL programmes (Makori 2011: 35). Some lessons can be learnt from the Botswana Library and the University of South Africa (Unisa) Library. As Nfila (2010) observed, the University of Botswana Library plans to take advantage of the simplicity of producing podcasts to record course lectures and tutorials and post them to the library blog for download and use by students registered in e-learning programs. Unisa Library is already using social media to market and expand library and information services to their ODL library users.

Aside from using social media for ODL, librarians are increasingly using them for Information Literacy (IL) programmes (Luo 2009). Using social media applications such as blogs, wikis, social networking, RSS feeds, Flickr and YouTube in an IL course can be seen as a unique enhancement to the e-learning environment (Penzhorn 2013). Proficiency in the use of social media fits within the information skills requirements for the twenty-first century librarian (Fernandez-Villavicencio 2010, Farkas 2012).

Social media applications have many advantages and disadvantages. One of the greatest advantages is that they offer innovative tools for libraries to use (Penzhorn \& Pienaar 2009). The platforms potentially offer enhanced interaction between librarians and patrons; quick communication and feedback is possible (Kwanya, Stillwell \& Underwood 2012). Social media improves section management in the library through integration of cataloguing resources for cataloguing departments (Xu, Ouyang \& Chu 2009).

Conversely, several concerns have been raised about the use of social media in academic libraries. One of the major constraints of using social media effectively is time. Librarians believe that social media tools are relatively technical and require time to learn, but because of work demands, librarians' time is limited (Cohen 2011, Chu \& Du 2013). Collins and Quan-Haase (2012: 2) maintain that librarians are of the opinion that social media platforms are time-consuming and too engrossing to use, as they need to be constantly updated. Other concerns include inadequate Information and Communication Technology (ICT) infrastructure and lack of familiarity with social media. Librarians in studies conducted by Arif and Mahmood (2012) and Hosseini and Hashempour (2012) identified inadequate computers and internet facilities, as well as lack of knowledge of the use of social media as their major constraints in adopting these platforms.

Factors affecting the use of social media tools in libraries are highlighted in various scholarly papers. 'Perceived usefulness' and 'perceived ease of use' seem to be the dominant determinants. Spacey, Goulding and Murray (2004) reported that librarians in the UK are convinced that internet technologies make their job easier by allowing efficient communication among staff and library users; they consequently use them a great deal. Aharony (2013) fused the TAM and the Big Five model of personality traits to investigate factors affecting the adoption of Facebook by librarians in Israel. Social media tools such as Facebook, Twitter and other online chat facilities allow librarians in India to collaborate with librarians within India and in other countries, consequently boosting the current use of such technologies in libraries (Thanuskodi 2012). However, issues to do with firewalls, the frequent need to use passwords to access the technologies, and slow internet response times are of concern to librarians in the UK (Spacey, Goulding \& Murray 2004).

The lack of the necessary skills is widely reported across the literature as a contributing factor for low use of social media tools. Thanuskodi (2012) reported that lack of social media skills among library staff discourages them from using these technologies and this has prompted library managers periodically to conduct computer and internet training for their staff. Ezeani and Igwesi (2012) revealed that lack of awareness and training among the library professionals in Nigeria has drastically contributed to the non-use of social media in the library environment. Other reasons for non-use include poor bandwidth (Munatsi 2010, Makori 2011), frequent electricity blackouts and internet filtering (Sarrafzadeh, Hazeri \& Alavi 2011).

The reviewed literature shows that, despite several obstacles, the implementation of social media is advancing, and that these applications will likely play a pivotal role in library service provision in the future. It has been discussed above that social media tools bring a wide range of benefits to academic libraries, hence the need to promote their integration and implementation. The following section discusses the key findings of the study. 


\section{Discussion of findings}

The findings of this study, which investigated the use of social media by librarians at UWC in South Africa and NUST in Zimbabwe, are discussed below. The discussion provides a detailed reflection on the findings based on the librarians' awareness and familiarity with social media, the purposes for which they use it, advantages and disadvantages of its use, and factors influencing its use and non-use.

\subsection{Librarians' awareness of and familiarity with diverse social media}

In this study, librarians' awareness of and familiarity with different social media applications was measured through discovering librarians' general awareness of the existence of specific social media applications, the extent of time they had been using social media, where they access social media and the frequency of their social media use .

Figure 1 summarises responses based on librarians' familiarity with diverse social media. Evident in Figure 1 is that librarians from both universities were aware of Facebook, WhatsApp, Linkedln, Google Chat, Twitter, YouTube, Skype and blogs and wikis. Clearly shown is that UWC librarians had a higher appreciation of all social media presented to them. In contrast, NUST librarians were less familiar with some of the social media platforms presented to them, for example, MXit and Viber.

Figure 1 Familiarity with social media at NUST and UWC

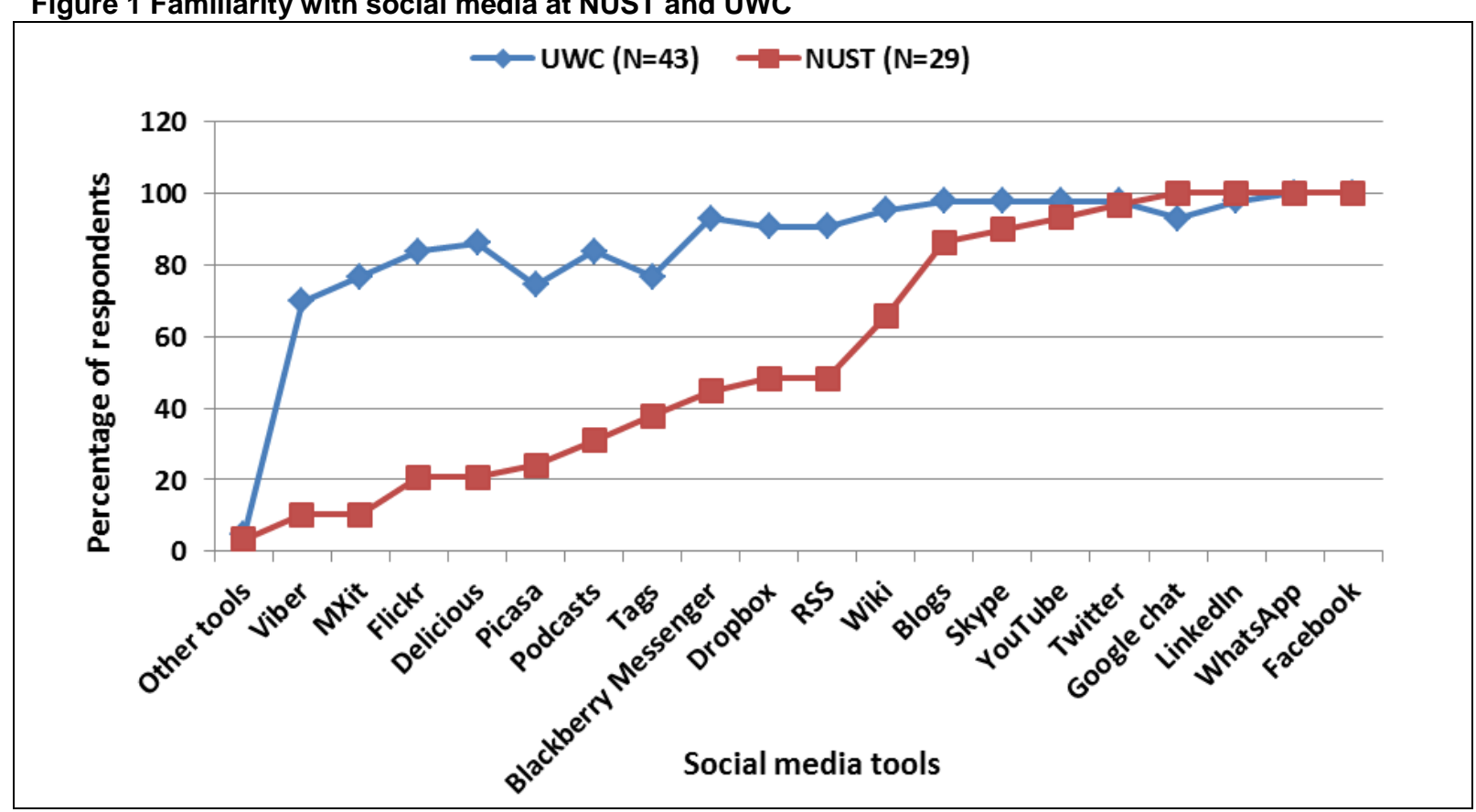

Figure 2 reveals that, in terms of places of access, twenty-six (89.7\%) NUST and forty-three (100\%) UWC librarians accessed social media tools at home. Only three (7\%) UWC and ten (34.5\%) NUST librarians accessed social media platforms in internet cafes. The higher number of librarians accessing these tools at home implies that they are always connected to the internet and are frequent users of these social media. It also points to blurred boundaries between the professional and the personal in terms of social media use among librarians. The frequency of use is fuelled by the ease of use and the usefulness of social media applications, as explained by the TAM theory used in this study.

More than twenty-one (72.4\%) NUST librarians used Google Chat, Facebook, WhatsApp, Linkedln, YouTube and Twitter. Similarly, thirty-one (72.1\%) UWC librarians used WhatsApp, Google Chat, Facebook, YouTube, Twitter, Linkedln, Blackberry Messenger and blogs many times a day. Thus, it can be stated with certainty that Google Chat, Facebook, WhatsApp, Linkedln, YouTube and Twitter were the social media mostly used by librarians in both libraries. Library staff had a high level of engagement with these tools because they frequently used them and had been using them for a long period of time. The TAM theory explains that individuals effectively use technology if they perceive it to be useful and easy to use.

World Wide Worx (2014) and Vermeulen (2013) revealed that Blackberry Messenger used to dominate all social media applications in South Africa because of the predominance of Blackberry smartphones. Now, however, WhatsApp has taken the lead. In contrast, at the NUST Library, there was a high usage of WhatsApp mobile applications; most librarians were less familiar with Blackberry Messenger as a consequence of not owning a Blackberry smartphone. A tool mentioned by NUST librarians was Yokoos, a social media tool developed in African countries. Its use is widespread within Zimbabwean society since its access is coordinated by a network provider (Econet Wireless) within the country.

In both libraries in the present study, tools such as Flickr and Picasa were not used for the storing and sharing of photographs as there was a high usage of Facebook which can be used for the same purposes. This finding is important to mention as Chisenga and Chande-Mallya (2012) note that some social media tools have similar functionalities; hence, 
individuals may not see the need to have dedicated accounts on both Facebook and Flickr, for example. For this reason, librarians may have found Facebook more useful in their personal and work spheres compared to Flickr and Picasa.

UWC librarians are acquainted with a wider variety of social media platforms than the NUST Librarians. The reason is probably their better internet connectivity resulting from support from TENET, as well as a well-maintained and bigger ICT infrastructure. Collins and Quan-Haase (2012) and Kwanya, Stilwell and Underwood (2012) indicated that the geographical location as well as the size of the university has direct implications on the use of social media applications.

Figure 2 Places of access at NUST and UWC

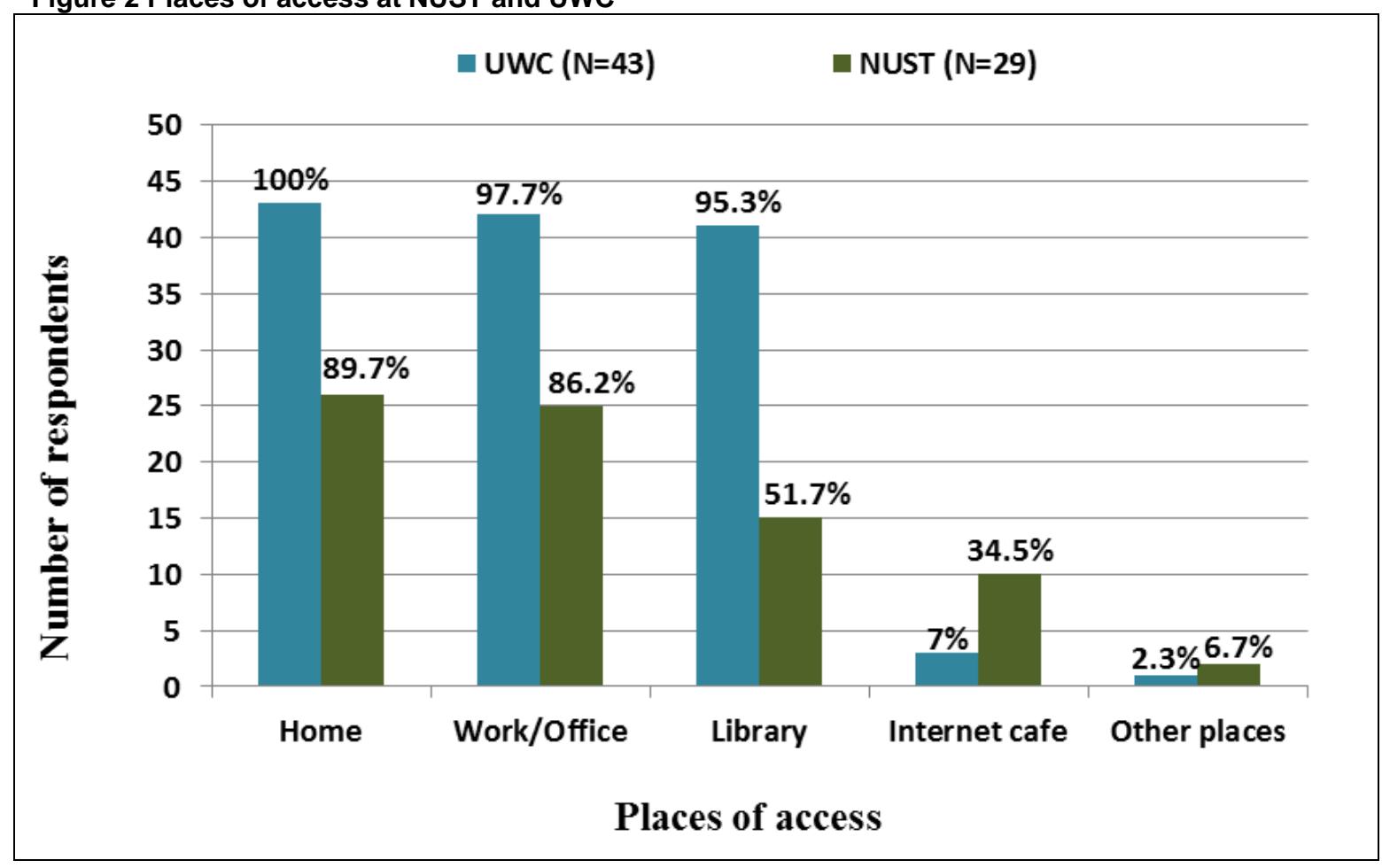

\subsection{Personal uses of social media by librarians}

This study further established that, although librarians from both universities were aware of the existence of wide-ranging social media technologies, they were selective in their use. Established in the study is that twenty-nine (100\%) NUST librarians and thirty-eight (88.4\%) UWC librarians used social media mainly for communicating with friends and family; twenty-nine (100\%) librarians at NUST and thirty-seven (86\%) librarians at UWC used the applications for entertainment; twenty-six (89.7\%) librarians at NUST and forty (93\%) librarians at UWC used tools for keeping abreast with current news; twenty-three (79.3\%) librarians at NUST and thirty-eight (88.4\%) librarians at UWC used the platforms for academic purposes; and nineteen (65.5\%) librarians at NUST and thirty-five (81.4\%) librarians at UWC used social media for archiving personal information.

Social media platforms such as Twitter, Facebook and WhatsApp were mainly used for communication and entertainment. Google Apps were mainly used for archiving information whereas YouTube was singled out as used for entertainment. Olasina (2011) notes that social media tools such as YouTube are powerful tools for leisure and, similarly, $\mathrm{Si}$, Shi and Chen (2011) comment that tools such as wikis and RSS feeds are mostly used for searching for information and following current events respectively. Trubitt and Overholtzer (2009: 91) state that librarians have incorporated these applications into their daily routines, using "Facebook, Twitter, Linkedln, online gaming environments, and other tools to build and maintain complex webs of professional and personal relationships".

\subsection{Work uses of social media by librarians}

At work, twenty-eight (96.6\%) NUST librarians and thirty-nine (90.7\%) UWC librarians used social media tools to offer reference services to users and to share work ideas with colleagues. Twenty-eight (96.6\%) NUST librarians and thirtyseven $(86 \%)$ UWC librarians used social media to interact with their users and to deliver IL programmes. Twenty-seven (93.1\%) librarians at NUST and thirty-six (83.7\%) at UWC used social applications to collaborate with colleagues in other libraries. Figures 3 and 4 below provide a summary of the responses from NUST and UWC respectively about their use of social media for work.

The use of social media at NUST for work purposes was confined to IT personnel and Subject Librarians, while at UWC, librarians' use differed according to position. The differences revealed in the study between job titles, qualifications, responsibilities and seniority in the use of social media explain some of the uses which were specific to particular librarians. For example, library evaluation (surveys, monitoring usage patterns) was conducted by the Deputy Director of the UWC Library who is in a senior management position. 
Figure 3 Use of social media tools in work spaces at NUST

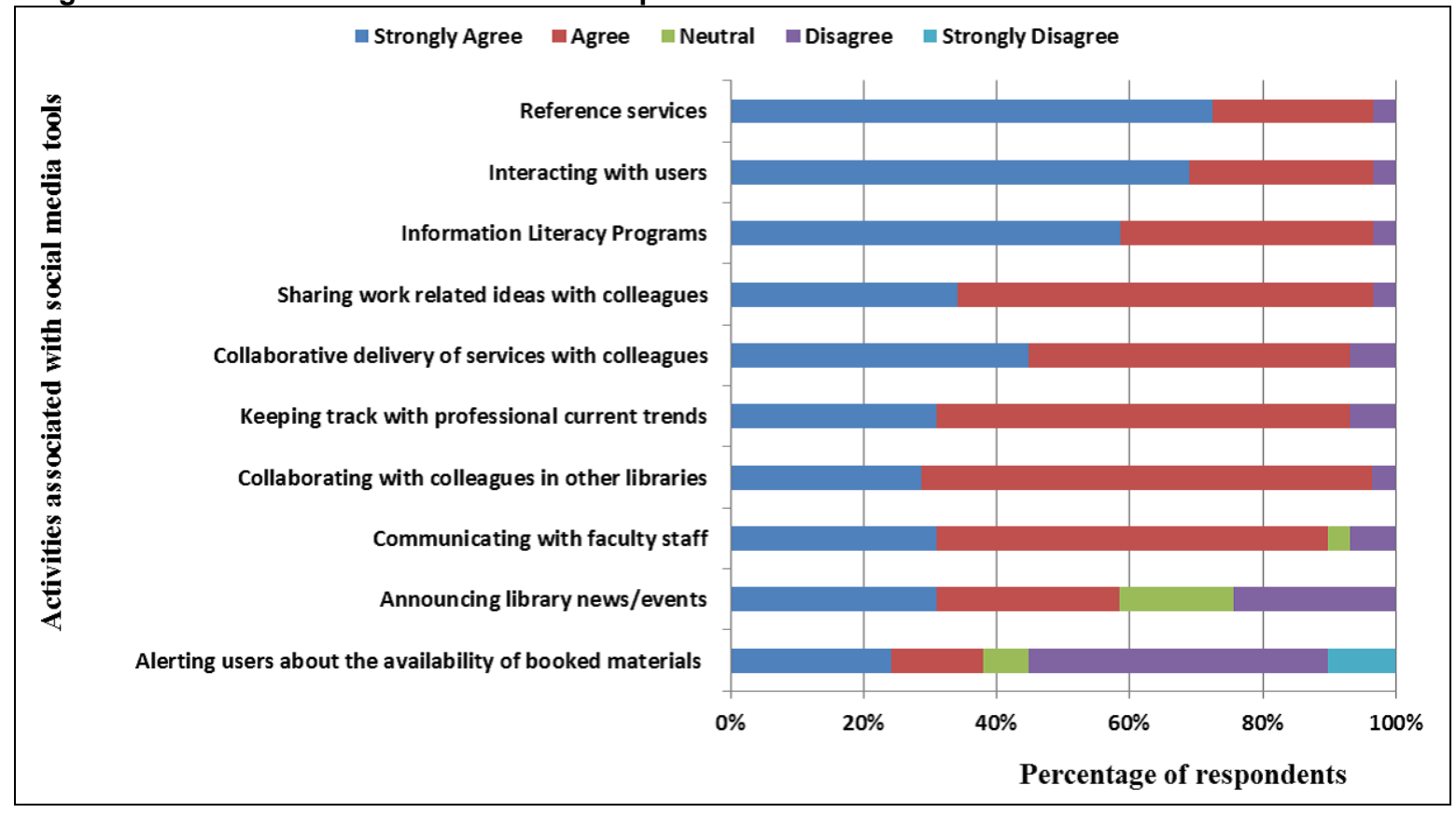

Figure 4 Use of social media tools in work spaces at UWC

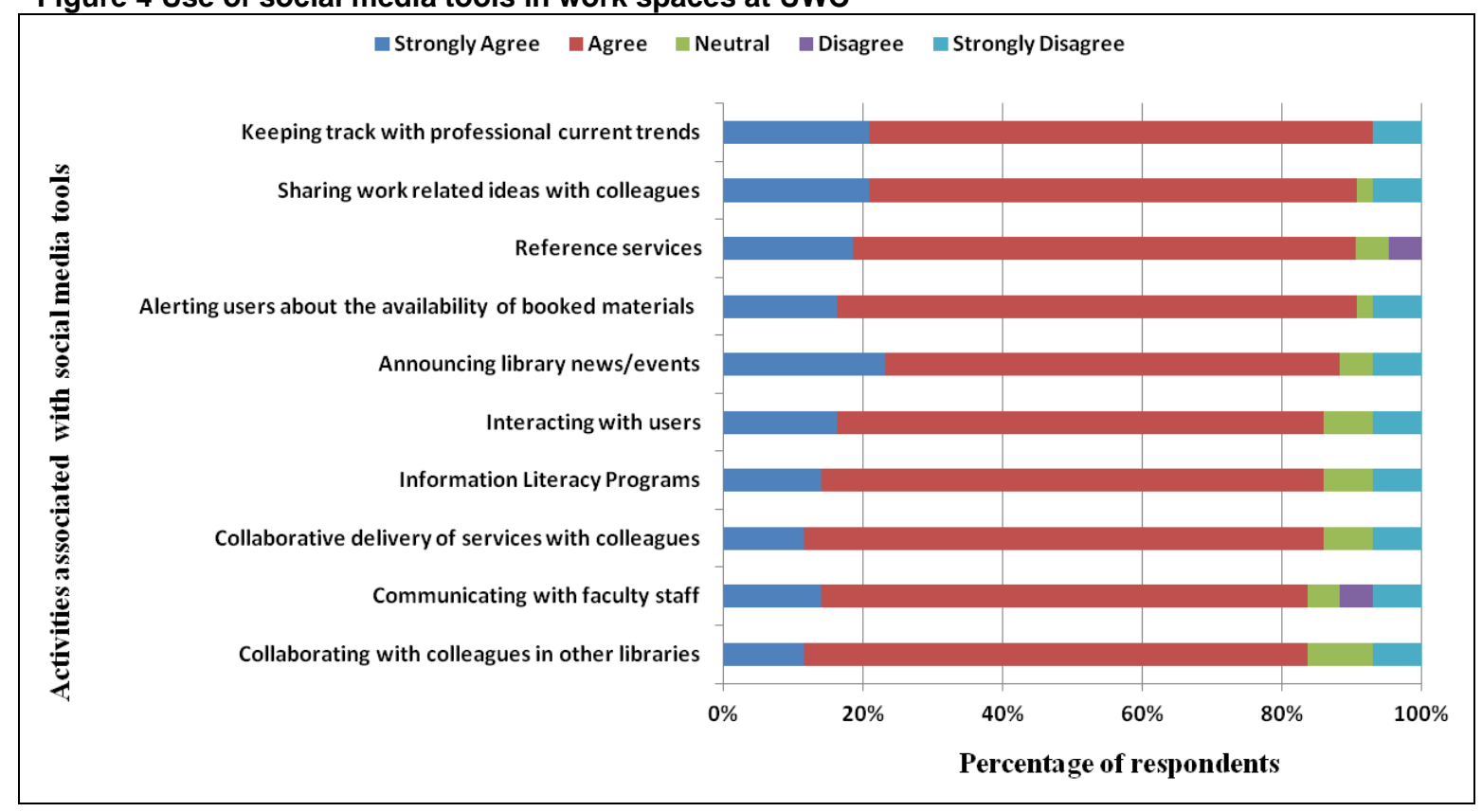

The study showed that personal use had a decisive effect on the use of social media tools at work; that is, if an individual did not use social media tools personally, it was difficult for him/her to use them at work. As one librarian expressed it, "one has to be familiar with the tools personally to effectively use them otherwise they can be useless at work".

In relation to the present study, librarians in both libraries have adopted and are using social media tools in their personal and work spheres. However, the pervasiveness and permeation of social media applications in librarians' everyday lives have resulted in blurred boundaries between their work and private lives, as these tools may be used anywhere and anytime. For instance, keeping track of current professional information through the use of social media can be both for personal satisfaction and beneficial for work. Reinforcing these findings is Olasina (2011) who argued that there is very little difference between uses of social media professionally and personally. Hence, the trend of management employing restrictive measures against the use of these tools at work.

UWC Library mostly used social media tools for marketing its services; the NUST Library mainly used them for reference services. The results at these libraries confirm observations made by Charnigo and Barnett-Ellis (2007) and Baro, Ebiagbe and Godfrey (2013), that librarians are using social media in different ways according to their own requirements. Baro, Ebiagbe and Godfrey (2013) found that librarians in South Africa used these tools for announcing library news while in Nigeria only a few librarians used the tools for the same purpose. 


\subsection{Factors influencing the use of social media}

Several factors motivate librarians to use social media. These factors are shown below in Figure 5 (NUST) and Figure 6 (UWC). All twenty-nine (100\%) NUST librarians and forty-one (95.3\%) UWC librarians were encouraged to use social media by its ease of use. Forty librarians at UWC (93\%) and twenty-eight librarians at NUST (96.6\%) mentioned that they were encouraged by the usefulness of social media tools. Twenty-two (75.9\%) librarians at NUST and thirty-six (83.7\%) at UWC indicated that they were motivated to use social media because of work commitment and cooperation.

Figure 5 Factors influencing the use of social media tools at NUST

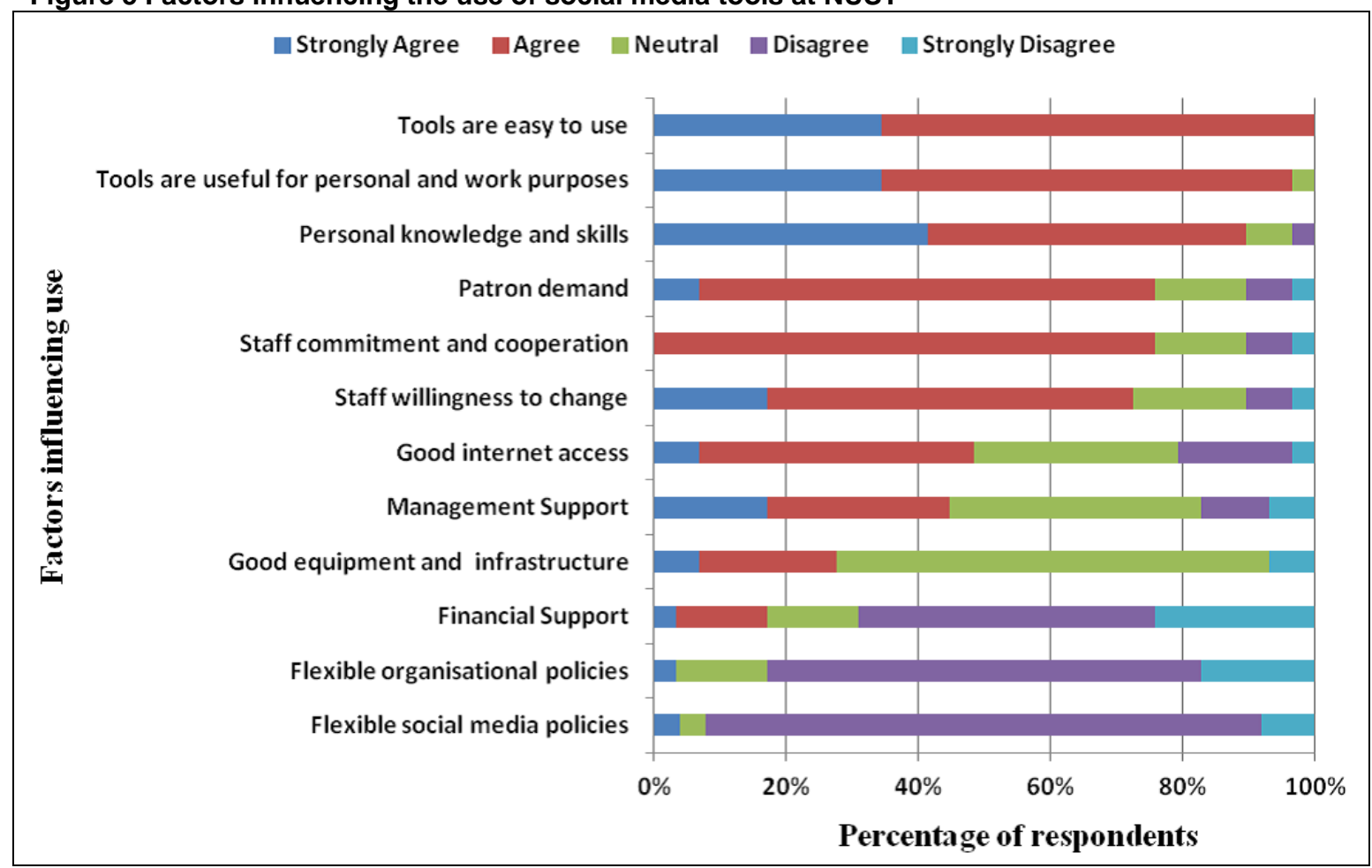

Figure 6 Factors influencing the use of social media tools at UWC

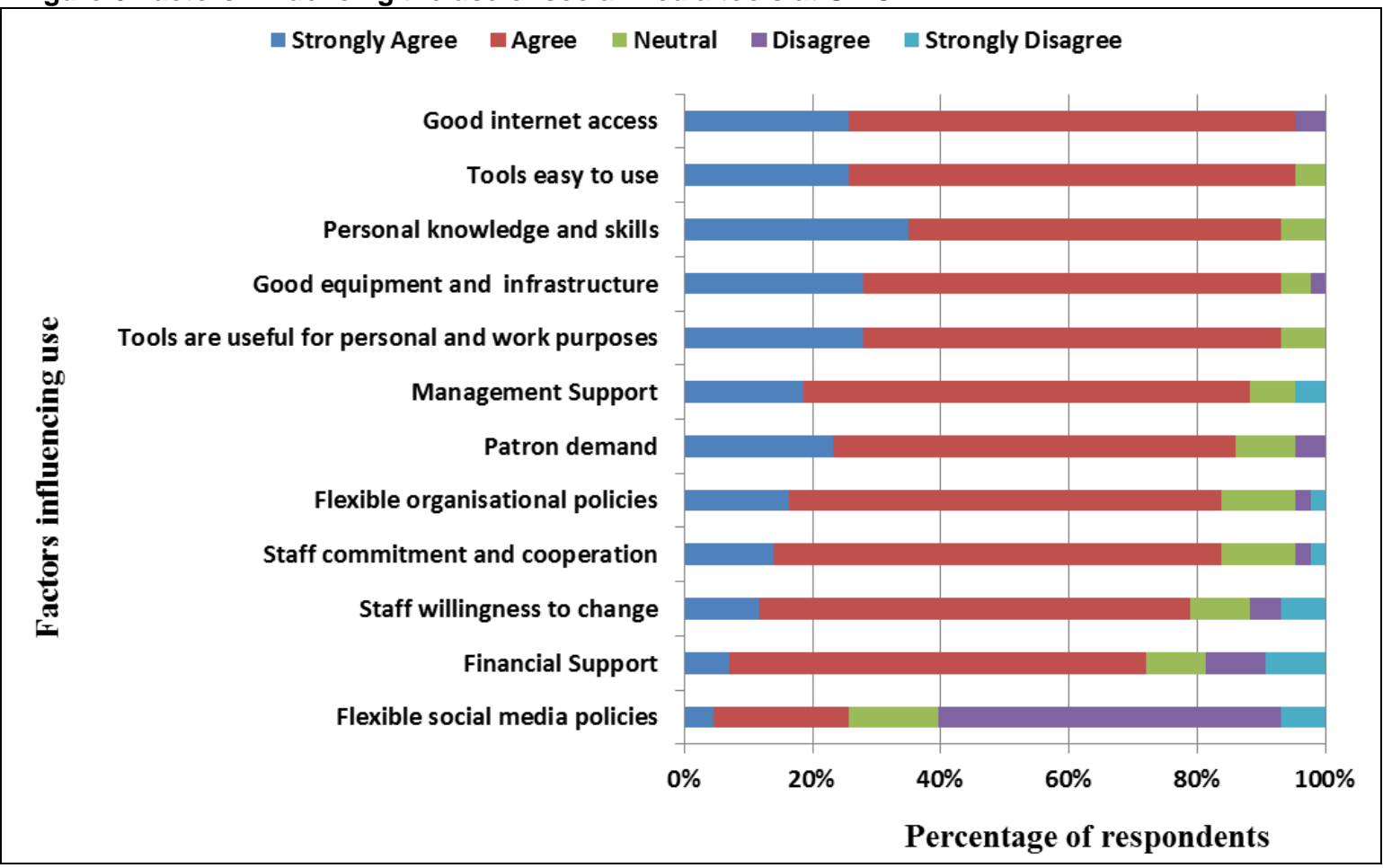

Over $75 \%$ of librarians in both universities identified three similar factors which motivate them to use social media. These factors are 'ease of use' and 'usefulness of the tools' as well as 'personal drive'. These trends reflect the TAM theory which holds that if an individual finds technological applications easy to use and useful (adding value to their work) 
they are bound to adopt and appreciate these tools. Arif and Mahmood (2012) and Hosseini and Hashempour (2012) reported similar findings: that frequency of use is directly affected by social media's ease of use.

The present study revealed that library users' high usage of these tools has led to librarians in turn adopting and using them. Librarians are striving to keep their users from overlooking the library by being present where they are, offering them convenient delivery of services anywhere and anytime. Kwanya, Stilwell and Underwood (2012) commented that today's patrons have high expectations of the modern academic library as technological advancement has given them more access to information than ever before.

Librarians also mentioned that the affordability of social media has heavily influenced them to use these platforms. Van Rooyen (2012) raised the point that these platforms are being used for academic purposes by most universities in South Africa because they can accommodate students who are financially constrained.

Another motivating factor for using social media identified in this study was the availability of mobile technologies owned either personally or institutionally. UWC Library offers mobile technologies such as e-readers and iPads (University of the Western Cape Library 2014). Complementing this finding, a spot check on the NUST Library website revealed that the library owns a mobile site which provides a compatible format for users to access library services on their personal mobile technologies (National University of Science and Technology Library 2014). Mobile technologies offer easy access to social media anywhere and at any time. As such, one librarian commented that "libraries will be forced to introduce mobile technologies as a way of complementing and increasing the use of these tools". This makes sense as Chisenga and Chande-Mallya (2012: 16) emphasise that using mobile (smartphones and tablet) and wireless internet technologies increases the effective use of social media.

\subsection{Factors for the non-use of social media}

One of the main goals of the study was to obtain the perspectives of librarians on the factors that discourage them from using social media. Figure 7 shows that twenty-five (86.2\%) NUST librarians were discouraged from making use of social media by lack of financial support. Also twenty-two (75.9\%) librarians at NUST were demotivated by the university's absence of social media policies and poor internet access. At the UWC Library, twenty-six (60.5\%) librarians agreed that the absence of social media policies was the only significant factor that discouraged them from using these tools, as can be seen in Figure 8.

Figure 7 Factors influencing the non-use of social media tools at NUST

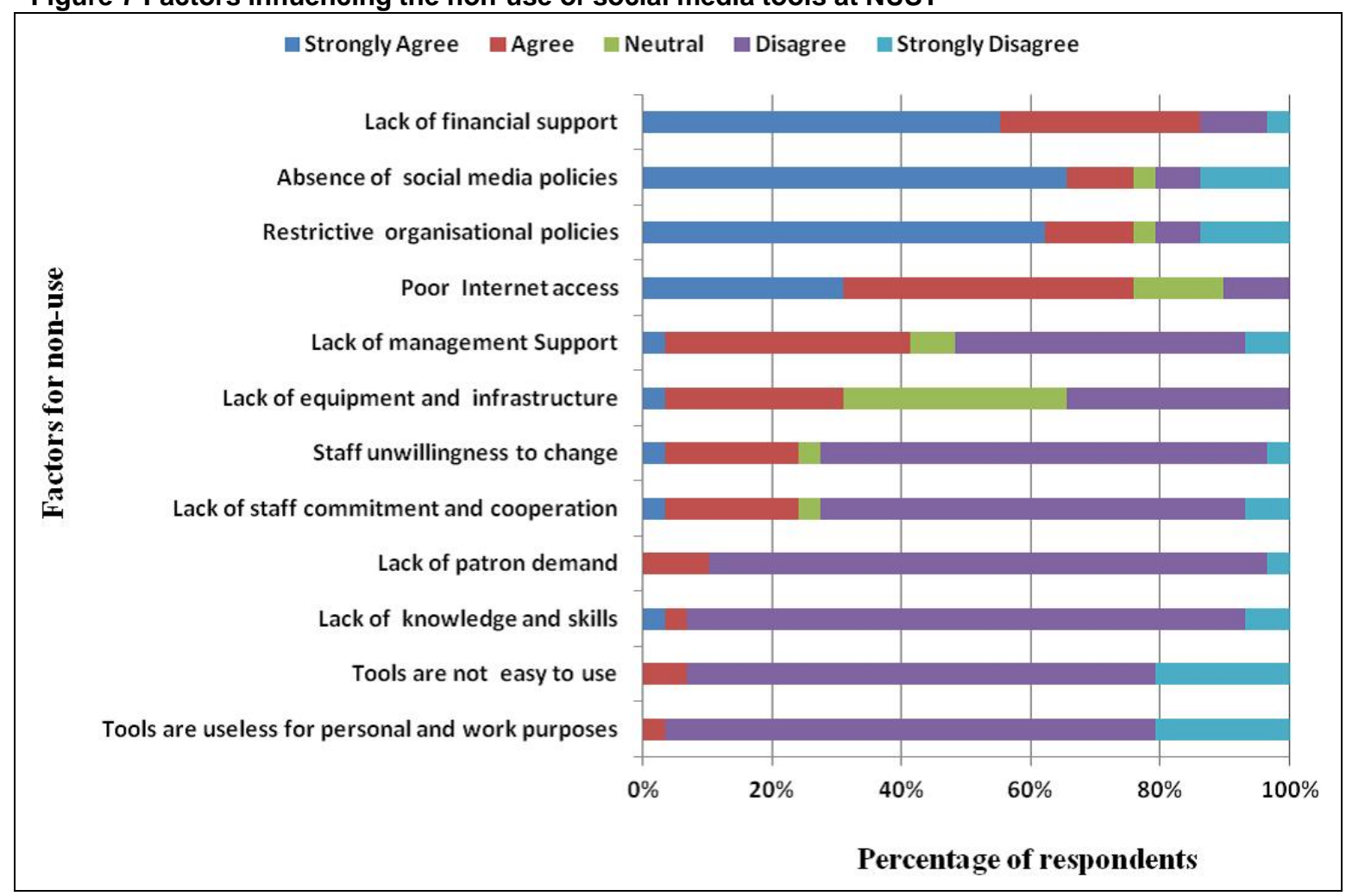

According to this study, one of the predominant discouraging factors is that the use of social media applications is time-consuming. Librarians made it clear that mismanagement of these tools results in work time being compromised. According to Boxen (2008) and Luo (2009), some social media platforms have proven to be more technical than others and demand a substantial amount of time from librarians to learn. Banda (2011), Chisenga and Chande-Mallya (2012: 16), and Chu and Du (2013) note that librarians across the world lack time to use social media effectively.

In connection with the finding above, librarians in both libraries were also concerned about the use of these applications in an academic library setting, referring to them as 'informal'. This finding echoes arguments made by 
Sekyere (2009), Cohen (2011) and Collins and Quan-Haase (2012), that academic libraries should not waste their time and resources on platforms that are largely meant for leisure. Given this premise, the effectiveness or positive impact of social media in academic libraries largely depends on whether librarians take the initiative and explore and use this type of technology or whether they reject it outright as frivolous entertainment (Charnigo \& Barnett-Ellis 2007).

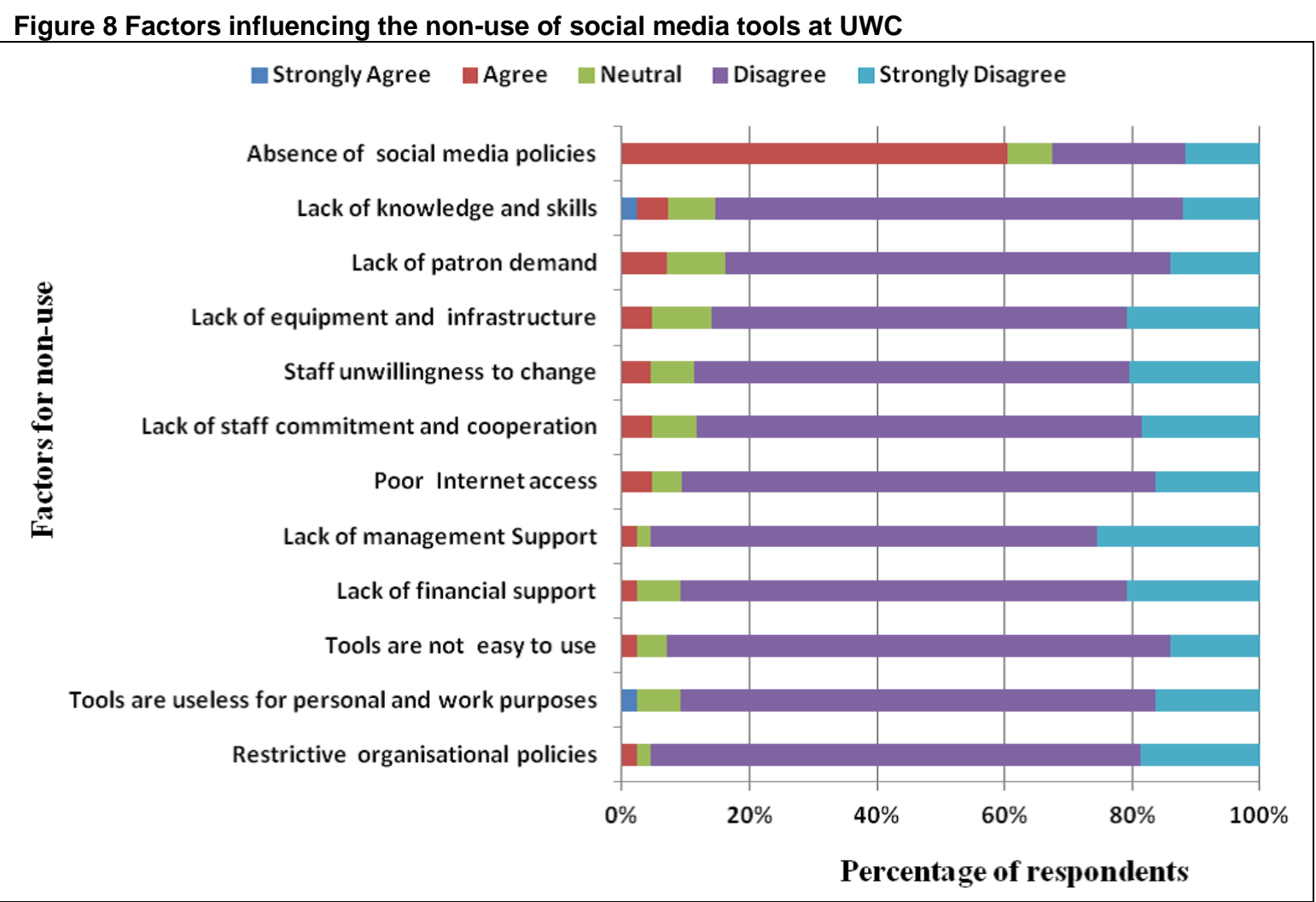

While the results show that the robust internet at UWC encouraged librarians to use social media tools, poor internet was a major impediment to the use of social media tools at NUST. There is visible disparity between librarians at the two universities where only fourteen (48.2\%) librarians at NUST compared to forty-one $(95.3 \%)$ librarians at UWC were motivated by their internet access to make use of social media. The differences in internet connectivity between the two countries might be the result of a different economic status. In Zimbabwe, university funding for internet access relies heavily on student fees while in South Africa, tertiary institutions are supported by TENET through the SANReN project which offers public universities first-preference, affordable and high speed networking (Wright 2011).

Another major impeding factor highlighted in the study was the absence of social media policies in both libraries. Academic libraries are known to prefer the formulation of social media policies as situations arise (Kooy \& Steiner 2010). As social media policies provide guidance on how to manage time, mode of expression and content, the practice of writing policies in response to specific situations is a risk which might allow for a loophole through which some individuals could misuse applications (Oosman, McMillan \& Bell 2014). Therefore, there is an urgent need to put in place social media policies which will govern the use of these applications by librarians (Blank \& Reisdorf 2012). According to a respondent at UWC however, most social media policies are inflexible, restricting creativity and spontaneity among librarians which in turn contributes to the ineffective use of social media. Johnson and Burclaff (2013) comment that most social media policies are risk-averse since these technologies are subject to abuse and lack security and privacy.

\section{Concluding remarks}

This study established that the two academic libraries, UWC in South Africa and NUST in Zimbabwe, are still trying to find their feet with regards to social media. At the same time, it is clear that a social media presence is no longer foreign to libraries in developing countries. The study revealed that personal use has influenced professional use and that there is a thin line between the use of social media for personal reasons and at work.

It also emerged that librarians at both universities are well aware of the benefits and controversies that come with the use of social media. Social media assists librarians to move away from their more traditional roles.

The Technological Acceptance Model played a pivotal role in helping to make sense of the findings of the study. The theoretical framework revealed that ease of use and usefulness of social media encouraged librarians to use and adopt the applications. The absence of social media policies is the most visible impeding factor in both libraries. Other negative factors identified are poor internet connectivity in Zimbabwe, and the issue of time constraints. Based on the conclusions, the following recommendations are proposed:

Since the study concluded that there is a thin line between use in personal and work spheres, it is important to design social media policies which govern the use of social media at work. Therefore, library management at both universities 
should craft supportive social media policies to encourage effective use of social media tools. Both library managements should encourage their staff to update their skills constantly through staying in touch with current technological trends. The NUST Library should extend the management of social media tools to library professionals and not leave this work to IT professionals only.

\section{References}

Aharony, N. 2009. Web 2.0 use by librarians. Library and Information Science Research, 31(1): $29-37$.

Aharony, N. 2013. Factors affecting the adoption of Facebook by information professionals. Proceedings of the Association for Information Science and Technology. 50(1): 1-10. [Online]. http://onlinelibrary.wiley.com/doi/10.1002/meet.14505001030/full (20 August 2013).

Arif, M. and Mahmood, K. 2012. The changing role of librarians in the digital world: adoption of Web 2.0 technologies by Pakistani librarians. The Electronic Library, 30(4): 469-479.

Banda, C. 2011. Use of social networking tools in libraries in Zambia. Chisenga's Trails. 12 August. [Online]. http://justinchisenga.blogspot.com/2011/08/social-networking-tools-in-libraries-in.html (22 August 2013).

Baro, E.E., Ebiagbe, E.J. and Godfrey, V.Z. 2013. Web 2.0 tools usage: a comparative study of librarians in university libraries in Nigeria and South Africa. Library Hi Tech, 5(1): 10-20.

Blank, G. and Reisdorf, B.C. 2012. The participatory web. Information, Communication and Society, 15(4): 537-554.

Boxen, J. 2008. Library 2.0: a review of the literature. The Reference Librarian, 49(1): 21-34.

Charnigo, L. and Barnett-Ellis, P. 2007. Checking out Facebook.com: the impact of a digital trend on academic libraries. Information Technology and Libraries, 26(1): 23-34.

Chisenga, J. and Chande-Mallya, R. 2012. Social media and professional networking: a case of information professionals in the SCECSAL region. Paper presented at the $20^{\text {th }}$ Standing Conference of Eastern, Central, Southern African Library and Information Associations (SCECSAL). 4-8 June 2012. Nairobi, Kenya. [Online]. http://scecsal.viel.co.ke/images/c/c0/Social_Media_and_Professional_Networking_A_Case_o f_Information_Professionals_in_the_SCECSAL_Region.pdf (25 September 2014).

Chitanana, L. 2012. Bandwidth management in universities in Zimbabwe: towards a responsible user base through effective policy implementation. International Journal of Education and Development using Information and Communication Technology, 8(2): 62-76.

Chu, S.K. and Du, H.S. 2013. Social networking tools for academic libraries. Journal of Library and Information Science, 45(1): 64-75.

Cohen, H. 2011. 30 social media definitions. [Online]. http://heidicohen.com/social-media-definition/ (27 August 2014).

Collins, G. and Quan-Haase, A. 2012. Social media and academic libraries: current trends and future challenges. Proceedings of the Association for Information Science and Technology. 49(1): 1-4. [Online]. http://onlinelibrary.wiley.com/doi/10.1002/meet.14504901272/full (13 June 2013).

Davis, F.D. 1989. Perceived usefulness, perceived ease of use and user acceptance of information technology. Management Information Systems Quarterly, 13(3): 319-340.

Ezeani, C. N. and Igwesi, U. 2012. Using social media for dynamic library services delivery: the Nigerian experience. Library Philosophy and Practice. [Online]. http://digitalcommons.unl.edu/libphilprac/814 (15 June 2013).

Farkas, M. 2012. Participatory technologies, pedagogy 2.0 and information literacy. Library Hi Tech, 30(1): $82-94$.

Fernandez-Villavicencio, N.G. 2010.Helping students become literate in a digital, networking based society: a literature review and discussion. International Information and Library Review, 42(1): 124-136.

Gerolimos, M. and Konsta, R. 2011. Services for academic libraries in the new era. Magazine of Digital Library Research, 17(8): 1-13.

Harinarayana, N. and Raju V. 2010. Web 2.0 features in university library web sites. The Electronic Library, 28(3): 69-88.

Hosseini, E. and Hashempour, L. 2012. The status of librarians' knowledge sharing by the usage of Web 2.0 tools: a case study of central libraries of Tabriz governmental universities. E-Science Communications in Computer and Information Science, 317: 128-137. [Online]. http://by2012.bilgiyonetimi.net/proceedings/hosseini_hashempour.pdf (20 March 2014).

Johnson, C. and Burclaff, N. 2013. Making social media meaningful: connecting missions and policies. Imagine, innovate, inspire: proceedings of the ACRL 2013 Conference. 10-13 April 2013. Indianapolis, IN.: ACRL. [Online]. http://www.ala.org/acrl/sites/ala.org.acrl/files/content/conferences/confsandpreconfs/2013/papers/JohnsonBurclaff_M aking.pdf (25 March 2014).

Kaplan, A. M. and Haenlein, M. 2010. Users of the world, unite: the challenges and opportunities of social media. Business Horizons, 53(1): 59-68.

Kibugi, S. 2013. The use of social media in the dissemination of information in selected public and private university libraries in Kenya. Innovation, 47(1): 101-120.

Kim, Y. and Abbas, J. 2010. Adoption of Library 2.0 functionalities by academic libraries and users: a knowledge management perspective. Journal of Academic Librarianship, 36(3): 211-218.

Kooy, B.K. and Steiner, S.K. 2010. Protection, not barriers: using social software policies to guide and safeguard students and employees. Reference and User Services Quarterly, 50(1): 59-71.

Kruss, G. and Gastrow, M. 2015. Linking universities and marginalised communities: South African case studies of innovation focused on livelihoods in informal settings. Cape Town: Human Sciences Research Council and 
International Development Research Centre. [Online].

http://www.hsrcpress.ac.za/product.php?productid=2331\&freedownload=1 (17 August 2015).

Kwanya, T., Stilwell, C. and Underwood, P.G. 2012. Techno-stress and techno-lust: coping mechanisms among academic librarians in Eastern and Southern Africa. Proceedings of the International Conference on ICT Management.17-18 September 2012. Wroclaw: Poland. 302-313. [Online]. www.globdev.org/files/ICTM2012_Proceedings.pdf (22 August 2014).

Luo, L. 2009. Web 2.0 integration in information literacy instruction: an overview. Journal of Academic Librarianship, 36(1): 32-40.

Mahmood, K. 2011. Impact of Web 2.0 technologies on US academic libraries: a study of ARL libraries. PhD thesis. University of the Punjab,

Makori, E.O. 2011. Bridging the information gap with the patrons in university libraries in Africa: the case for investments in Web 2.0 systems. Library Review, 61(4): 340-350.

Moran, B.B. and Leonard, E. 2009. Academic librarianship. In: Encyclopaedia of Library and Information Sciences. $3^{\text {rd }}$ ed. J. D. Mcdonald and M. Levine-Clark, Eds. New York: Taylor Francis. 1-10.

Munatsi, R. 2010. Implementation of library 2.0 services in African academic and research libraries: need for fundamental rethink. Proceedings of the $19^{\text {th }}$ Standing Conference of Eastern, Central, Southern African Library and Information Associations (SCECSAL). 6-9 December 2010. Gaborone, Botswana: SCECSAL. [Online]. http://www.scecsal.org/conferences/2010/spapers2010.pdf (15 June 2013).

National University of Science and Technology Library. 2014. Library: National University of Science and Technology. [Online]. http://library.nust.ac.zw/ (20 September 2014).

Nfila, R.B. 2010. Academic libraries support for e-learning: initiatives and opportunities the case of University of Botswana Library. [Online]. http://www.ais.up.ac.za/digi/docs/nfila_paper.pdf (8 June 2013).

Olasina, G. 2011. The use of Web 2.0 tools and social networking sites by librarians, information professionals, and other professionals in the workplaces in Nigeria. PNLA Quarterly, 75(3): 11-39.

O'Leary, Z. 2004. The essential guide to research. London: Sage publications.

Oosman, A., McMillan, J. and Bell, J. 2014. Use of social media by the library: current practices and future opportunities. Oxford: Taylor \& Francis. [Online]. http://www.tandf.co.uk/journals/access/white-paper-social-media.pdf (5 January 2014).

Penzhorn, C. 2013. The use of social media in teaching a campus-wide information literacy course. Mousaion, 31(3): 5773.

Penzhorn, C. and Pienaar, H. 2009. The use of social networking tools for innovative delivery at the University of Pretoria library. Innovation, 36(1): 66-77.

Rogers, C.R. 2009. Social media, libraries and Web 2.0: how American libraries are using new tools for public relations and to attract new users. Columbia, SC: South Carolina State Library. [Online]. http://dc.statelibrary.sc.gov/bitstream/handle/10827/7271/SCSL_Social_Media_Libraries2011.pdf?sequence=1 (26 August 2013).

Sarrafzadeh, M., Hazeri A. and Alavi, S. 2011. The status of Web 2.0 in Iran's LIS education. Education for Information, 28(2): 233-245.

Sekyere, K. 2009. Too much hullabaloo about Facebook in libraries: is it really helping libraries? Nebraska Library Association Quarterly, 40(2): 25-37.

$\mathrm{Si}, \mathrm{L}$., Shi, R. and Chen, B. 2011. An investigation and analysis of the application of Web 2.0 in Chinese university libraries. The Electronic Library, 29(5): 651-668.

Spacey, R., Goulding, A. and Murray, I. 2004. Exploring the attitudes of the public library staff to the internet using the TAM. Journal of Documentation, 60(5): 550-564.

Stephens, M. 2006. Exploring Web 2.0 and libraries. Library Technology Reports, 42(6): 8-14.

Thanuskodi, S. 2012. Awareness of library 2.0 applications among library and information science professionals at Annamalai University, India. International Journal of Library Science, 1(5): 75-83.

Tripathi, M. and Kumar, S. 2010. Use of Web 2.0 tools in academic libraries: reconnaissance of the international landscape. The International Information and Library Review, 42(3): 195-207.

Trubitt, L. and Overholtzer, J. 2009. Good communication: the other social network for successful IT organizations. EDUCAUSE Review, 44(6): 90-98.

University of the Western Cape Library. 2014. University of Western Cape Library. [Online]. http://lib.uwc.ac.za/ (20 September 2014).

Van Rooyen, A. 2012. Student experiences of technology integration at Unisa. Progressio, 1(1): 1-7.

Vanwynsberghe, H., Vanderlinde, R., Georges, A. and Verdegem, P. 2015. The librarian 2.0: identifying a typology of librarians' social media literacy. Journal of Librarianship and Information Science, 47(4): 283-293.

Vermeulen, J. 2013. WhatsApp vs BBM vs MXit vs 2 go in South Africa. MyBroadband. 12 September. [Online]. http://mybroadband.co.za/news/internet/86783-whatsapp-vs-bbm-vs-mxit-vs-2go-in-south-africa.html (21 August 2014).

Witte, G.G. 2014. Content generation and social network interaction within academic library Facebook pages. Journal of Electronic Resources Librarianship, 26(2): 89-100.

World Wide Worx. 2014. South African Social Media Landscape 2014. [Online]. http://www.worldwideworx.com/wpcontent/uploads/2013/10/Exec-Summary-Social-Media-2014.pdf (11 November 2014). 
Wright, C. 2011. SANReN: Past, present and future. [Presentation]. 11 November. [Online]. http://www.paerip.org/sites/www.paerip.org/files/Colin_Wright.pdf (25 September 2014).

Xu, C., Ouyang, F. and Chu, H. 2009. The academic library meets Web 2.0: applications and implications. Journal of Academic Librarianship, 35(4): 324-331. 